\author{
$@(0 \otimes$ \\ Jurnal Terapan Manajemen dan Bisnis is licensed under \\ A Creative Commons Attribution-Non_Commercial 4.0 International License.

\section{Income Smoothing Analysis in the Company (Case Study at PT. Kalbe Farma. Tbk Year 2017-2019) \\ Irvan Yoga Pardistya ${ }^{1)}$} \\ 1) Universitas Singaper bangsa, Karawang, Indonesia \\ E-mail: irvan.yoga @fe.unsika.ac.id
}

\begin{abstract}
Profit is a goal orientation in the company's operations. For this reason, the performance of a company can be measured from the profits it gets. Income smoothing, in another case, is one of the methods used in distributing variations in profit achievement in a company's financial statements. This research, intends to describe the income smooting that has been achieved by PT. Kimia Farma Tbk. The research object is PT. Kimia Farma Tbk. Then, the unit of analysis is the company's financial statements for 2017-2019. Furthermore, the analysis technique uses quantitative descriptive. The results of the analysis explain that the company's Income smoothing is fluctuating. This can be seen from the increase in income smoothing in 2017 to 2018 which has increased, but 2018 to 2019 has decreased.
\end{abstract}

Keywords: Income Smoothing; Revenue

\title{
Introduction
}

Company is a profit-oriented organization. The company's profit is the goal of moving the company. In addition, profit is one measure of a company's success. It is appropriate that profit is one of the reviews in the company. Thus, the company can be assessed whether or not it is good from this aspect.

Furthermore, profit is one indicator of performance appraisal in a company. These indicators translate the activities of the company's operations. Then, profit can examine how the company operates. The operation is known by the results achieved by the company. For this reason, the company measures it against the results it gets.

PT. Kalbe Farma, Tbk is a company engaged in the manufacturing industry which produces pharmaceuticals. In its current movement, PT. Kalbe Farma, is one of the go-public companies. Apart from being a go-public company, the company has a good performance. This can be seen from the company's financial performance to be one of the companies listed on LQ 45 .

The companies listed on LQ 45 are the best companies in their performance. This is proven by the performance of liquid shares in the best 45 companies on the Indonesia Stock 
Exchange. In its journey, the company makes its financial performance good every year. However, profit planning and profit performance within the company must be managed properly. The profit must be distributed properly for the smooth operation of the company.

Then, company income or income is an indicator in predicting company profit. Company income is a source of income within the company. Furthermore, the income is calculated and evaluated into a profit-generating performance. The income earned by PT. Kalbe Farma, Tbk recently are as follows.

Tabel 1.1

Income PT. Kalbe Farma Tbk Tahun 2017-2019

\begin{tabular}{lccc}
\hline No & Nama Perusahaan & Tahun & Income \\
\hline \multirow{2}{*}{1} & & 2019 & 2.537 .601 .823 .645 \\
\cline { 3 - 4 } & PT. KALBE FARMA TBK. & 2018 & 2.497 .261 .964 .757 \\
\cline { 3 - 4 } & & 2017 & 2.453 .251 .410 .604 \\
\hline
\end{tabular}

Sumber : Data diolah

From the data in table 1.1 above, it can be seen that the company's income increases every year. The data also shows an increase in income by $10 \%$ each year. This shows a positive result in its operation. In addition, its performance is evaluated well every year. Thus, the income earned by the company moves up and is positive.

Switching from the company's income, one of the revenues the company gets is the result of sales. Proceeds from sales are one source of company income. In addition, the company's sales results describe the company's profit performance. This is because the sales revenue is the number that increases the profit from the company's performance. The results of the company's sales performance can be displayed as follows:

Tabel 1.2

Sales PT. Kalbe Farma Tbk Tahun 2017-2019

\begin{tabular}{lccc}
\hline No & Nama Perusahaan & Tahun & Income \\
\hline \multirow{2}{*}{ PT. KALBE FARMA TBK. } & 2019 & 22.633 .476 .361 .038 \\
\cline { 3 - 4 } & & 2018 & 21.074 .306 .186 .027 \\
\cline { 3 - 4 } & & 2017 & 20.182 .120 .166 .616 \\
\end{tabular}

Sumber : Data diolah

From the data in table 1.2 above, it can be seen how the company's sales results increase each year. Haa is directly proportional to the income the company gets. The rate of increase in sales each year is around $10 \%$. In getting sales, the company is categorized as good in its operations. Thus, the company's sales are increasing every year.

From the data described above, the company is considered good because of the positive results of the company's total income. Therefore, a good company should get positive 
results in each period. However, one interesting study in this regard is how the company distributes its profits for the company's operations. This is studied in income smoothing.

Income smoothing is a process of manipulating the timing of earnings or earnings reports so that reported earnings look stable. (Fuddenberg and Tirole). Reported income smoothing can be defined as a deliberate attempt to smooth or fluctuate the level of profit so that it is currently considered normal for a company. In this case, income smoothing represents an attempt by company management to reduce abnormal variations in earnings within the limits permitted in accounting practices and sound management principles. (Beidleman in Ghozali and Chariri). Thus, it can be concluded that income smoothing is an act of deliberate manipulation, which is carried out by management of the fluctuations in reported earnings so that the company's profits are at the level considered normal by the company or in other words so that the reported earnings of the company look stable as long as permitted by the principle sound accounting and management. For this reason, this research will take the theme of Income smoothing Analysis in Companies (Case Study at PT. Kalbe Farma. Tbk in 2017-2019).

Profit is one of the potential information contained in financial reports and is very important for internal and external parties to the company. Profit is the difference between the realization of income from company transactions in a certain period minus the costs incurred to get that income (Harahap, 2005). Profit is a measure of a company's financial performance in an accounting period and is the center of attention of users of financial statements (Indonesian Accounting Association, 2007).

Income smoothing is one of the patterns of earnings management (Cahan, 2008). The explanation of the concept of earnings management uses agency theory and positive accounting theory. Agency theory states that earnings management practices are influenced by conflicts of interest between management (agent) and owners (principal) that arise because of the desire to maximize their respective prosperity. Positive accounting theory is based on the proposition that managers, shareholders, and regulators are rational and they seek to maximize their usefulness, which is directly related to their compensation and welfare. The choice of an accounting policy by some of these groups depends on the relative comparison of the costs and benefits of alternative accounting procedures (Belkaoui, 2007b: 187). In line with the concept of earnings management, the concept of income smoothing also uses agency theory and positive accounting theory.

\section{Research Methodelogy}

\section{Population and Sample}

In this study the population is the company financial statements of PT. Kimia Farma Tbk when listing on LQ45 with purposive sampling technique. The samples are:

1. Consolidated Financial Statement Data for 2017 - 2019

2. Financial Report Data published in 2017-2019 


\section{Data Collection and Retrieval Procedures}

To collect the data needed in the study, the researcher used a type of data collection method, namely through the library research data collection method. Library research, which is a method of collecting data obtained by means of library research, which is obtained through library books as study material to discuss the problems under study.

\section{Analysis Technique}

The analysis technique in this research is quantitative descriptive analysis, namely statistical techniques that are generally used for descriptive data analysis, namely tables, graphs and average size.

\section{Result and Discussion}

The discussion in this research is focused on the income smoothing analysis, namely, how is income smoothing in 2017-2019.

\section{Income Smoothing}

Income smoothing shows the amount of income distribution that comes from income and sales. This is intended to see variations in earnings in financial statements. In addition, income smoothing is carried out so that the amount of profit stated in the company's financial statements has a positive distribution so that it shows good results. For this reason, the planning of income smoothing in the management of earnings, which is the final result of the company's performance, displays increasing results every year. The income smoothing data at PT. Kalbe Farma Tbk for 2017-2019 are as follows:

Tabel 1.3

Income Smootihng PT. Kalbe Farma Tbk Tahun 2017-2019

\begin{tabular}{cccccc}
\hline No & $\begin{array}{c}\text { Nama } \\
\text { Perusahaan }\end{array}$ & Tahun & Income & Sales & $\begin{array}{c}\text { Income } \\
\text { Somoothing }\end{array}$ \\
\hline \multirow{2}{*}{1} & & 2019 & 22.633 .476 .361 .038 & 22.633 .476 .361 .038 & 0,112117192 \\
\cline { 3 - 6 } & $\begin{array}{c}\text { Pt. Kalbe } \\
\text { Farma Tbk. }\end{array}$ & 2018 & 21.074 .306 .186 .027 & 21.074 .306 .186 .027 & 0,118497944 \\
\cline { 3 - 6 } & & 2017 & 20.182 .120 .166 .616 & 20.182 .120 .166 .616 & 0,121555683 \\
\hline
\end{tabular}

\footnotetext{
Sumber : Data diolah
} 
From the data in table 4.1 above, it can be described the increase and decrease of the company's income smoothing. The increase in the ratio in 2012 to 2018 is $10 \%$. However, there was a decrease in 2018 to 2019 by 6\%. These results indicate the distribution of income in fluctuating moving companies. Furthermore, a decreasing distribution of income represents a negative decrease in the amount of profit the company gets. The decline in profit can be predicted from the decline in revenue or sales the company received in 2 periods, namely 2018 and 2019.

\section{Conclusion}

Income smoothing at PT. Kalbe Farma Tbk. is fluctuation in each year. This can be seen from the increase in income smoothing in 2017 to 2018 which has increased, but 2018 to 2019 has decreased.

\section{References}

Belkaoui, Ahmed Riahi. 2007. Accounting Theory. Buku Satu dan Dua. Salemba Empat: Jakarta.

Cahan, Steven F, Guoping Liu, \& Jerry Sun. 2008. "Investor Protection, Income Smoothing, and Earnings Informativeness". Journal of International Accounting Research, 7 (1).

Harahap, S.S. (2005). Teori Akuntansi. Jakarta: PT. Raja Grafindo Persada.

Harahap, S.S. (2006). Analisis Kritis Atas Laporan Keuangan. Edisi Pertama. Jakarta: PT Raja Grafindo Persada.

Ikatan Akuntansi Indonesia, (2007). Standar Akuntansi Keuangan. Jakarta, PT. Salemba Empat.

Nasrullah HS, Zaki Fuad \& Muhammad Yasir Yusuf. 2014. Analisis Tindakan Perataan Laba Dalam Meraih Keuntungan Perusahaan Ditinjau Menurut Etika Ekonomi Islam. Volume 3, Number 2, July - December 2014. Fakultas Syariah IAIN Ar-Raniry Banda Aceh.

Ni Luh Putu Arik Prabayanti \& Gerianta Wirawan Yasa 2018. Perataan Laba (Income Smoothing) Dan Analisis Faktor-Faktor Yang Mempengaruhinya (Studi Pada Perusahaan Manufaktur Yang Terdaftar Di Bursa Efek Indonesia). Universitas Udayana. E-Jurnal Akuntansi Universitas Udayana. Vol.20.1. Juli (2017):496-525. 